\title{
ARIA Is Concentrated in Nerve Terminals at Neuromuscular Junctions and at Other Synapses
}

\author{
Alfred W. Sandrock, Jr., ${ }^{1,2}$ Andrew D. J. Goodearl, ${ }^{1}$ Qin-Wei Yin, ${ }^{1}$ David Chang, ${ }^{3}$ and Gerald D. Fischbach' \\ 'Department of Neurobiology, Harvard Medical School, Boston, Massachusetts 02115, 2Department of Neurology, \\ Massachusetts General Hospital, Boston, Massachusetts 02114, and ${ }^{3}$ Amgen, Inc., Thousand Oaks, \\ California 91320
}

\begin{abstract}
Skeletal muscle ACh receptors (AChRs) accumulate at neuromuscular junctions ( $\mathrm{nmjs}$ ) at least partly because of the selective induction of AChR subunit genes in subsynaptic myotube nuclei by the motor nerve terminal. Additionally, mammalian AChRs undergo a postnatal change in subunit composition from embryonic $\left(\alpha_{2} \beta \gamma \delta\right)$ to adult $\left(\alpha_{2} \beta \in \delta\right)$ forms, a switch that also depends on innervation. ARIA, a protein purified from chicken brains based on its ability to induce AChR synthesis in primary chick muscle cells, is a strong candidate for being the molecule responsible for these early developmental events. ARIA mRNA has been detected in embryonic motor neurons during synapse formation, and the gene continues to be expressed postnatally. In this report, we provide evidence that ARIA-like immunoreactivity is concentrated in rat motor nerve terminals from early postnatal ages, and that it can be detected in motor neurons in E18 embryos. ARIA is also detectable in axons within colchicine-treated sciatic nerves, suggesting that the protein in the nerve terminal has been transported from the cell body. ARIA mRNA is present in, but not restricted to, cholinergic neurons. Likewise, we report here that ARIA-like immunoreactivity is present in some noncholinergic central synapses. We also present evidence that isoforms of ARIA are differentially distributed among functionally distinct classes of neurons.
\end{abstract}

[Key words: synapse formation, neuromuscular junction, development, ACh receptor, Neu differentiation factor (NDF), heregulin (HER), glial growth factor (GGF), neuregulin, trophic factor]

At the vertebrate neuromuscular junction, ACh receptors (AChRs) are densely packed in the postsynaptic membrane. The motor nerve regulates the accumulation of AChRs in muscle in part by stimulating subsynaptic nuclei to increase AChR subunit mRNA (Merlie and Sanes, 1985; Sanes et al., 1991). In mammals, the motor nerve terminal is also crucial for the early post-

\footnotetext{
Received Jan. 23, 1995; revised May 15, 1995; accepted May 17, 1995

We thank our collaborators at Amgen, Inc., Thousand Oaks, CA, particularly Barry Ratzkin and Duanzhi Wen, for providing us with some of the antibodies, recombinant NDF, and NDF plasmids, without which this work would not have been possible. A.W.S. was supported by a Clinical Investigator Development Award from NINDS (NSO1580-02). This work was also supported by a grant from the NIH (NS18458), the Keck Foundation, the Charles $\Lambda$. Dana Foun dation, and the Muscular Dystrophy Association.

Correspondence should be addressed to Gerald D. Fischbach, Department of Neurobiology, Harvard Medical School, 220 Longwood Avenue, Boston, MA 02115 .

Copyright (C) 1995 Society for Neuroscience $0270-6474 / 95 / 156124-13 \$ 05.00 / 0$
}

natal maturation of AChRs at the neuromuscular junction, which results in the replacement of $y$-subunit-containing receptors with those containing $\boldsymbol{\epsilon}$ - subunits (Brenner and Sakmann, 1978; Brenner et al., 1990; Martinou and Merlie, 1991). ARIA (for ACh receptor inducing activity), which was purified from chicken brains based on its ability to stimulate the synthesis of AChRs in skeletal muscle (Falls et al., 1993), may mediate the ability of the motor neuron to orchestrate these developmental events. ARIA mRNA is concentrated in chick and rat motor neurons (Falls et al., 1993; Corfas et al., 1995), and, in both species, is detectable in these cells at the time nerve-muscle synapses begin forming (Corfas et al., 1995). ARIA stimulates the tyrosine phosphorylation of a $185 \mathrm{kDa}$ protein in both chick and rodent muscle (Corfas et al., 1993) and preferentially increases the synthesis of the $\epsilon$-subunit mRNA in mouse myotube cultures (Martinou et al., 1991). In addition, ARIA induces the synthesis of sodium channels in chick muscle cells (Corfas and Fischbach, 1993), a skeletal muscle protein whose accumulation in the subsynaptic membrane is also nerve dependent (Caldwell and Milton, 1988). Thus, the biological activity of ARIA, as well as the timing of the onset of its synthesis in motor neurons, is consistent with the hypothesis that it plays a pivotal role in the development and maintenance of the molecular architecture of mammalian neuromuscular junctions.

ARIA is a member of the Neu differentiation factor (NDF)/Heregulin (HER)/glial growth factor (GGF) family of ligands for a $185 \mathrm{kDa}$ receptor tyrosine kinase (Holmes et al., 1992; Peles et al., 1992; Wen et al., 1992; Marchionni et al., 1993). It exists as multiple isoforms, most of which appear to be synthesized as transmembrane precursor proteins, that is, proARIAs. Like other members of the heparin-binding EGF-like growth factor family, the extracellular portion of pro-ARIA is thought to be cleaved near the transmembrane domain to release soluble ARIA, which has been detected in medium conditioned by motor neurons and by COS cells transfected with ARIA cDNA (Corfas et al., 1993; Falls et al., 1993). ARIA contains an EGF-like domain, a 40 amino acid segment containing 6 cysteines with similar relative positions to other members of the EGF-like growth factor family, that is separated from an immunoglobulin-like motif by a "spacer" region. Analysis of mRNA sequence variation has revealed that the C-terminal portion of the EGF-like domain and the juxtamembrane stretch of ARIA appears to be encoded by two exons (Holmes et al., 1992; Wen et al., 1994). The first splice site, which distinguishes the two major classes of isoforms termed $\alpha$ and $\beta$, occurs at the 5th cysteine of the EGF-like domain. The $\alpha$-isoforms are expressed 


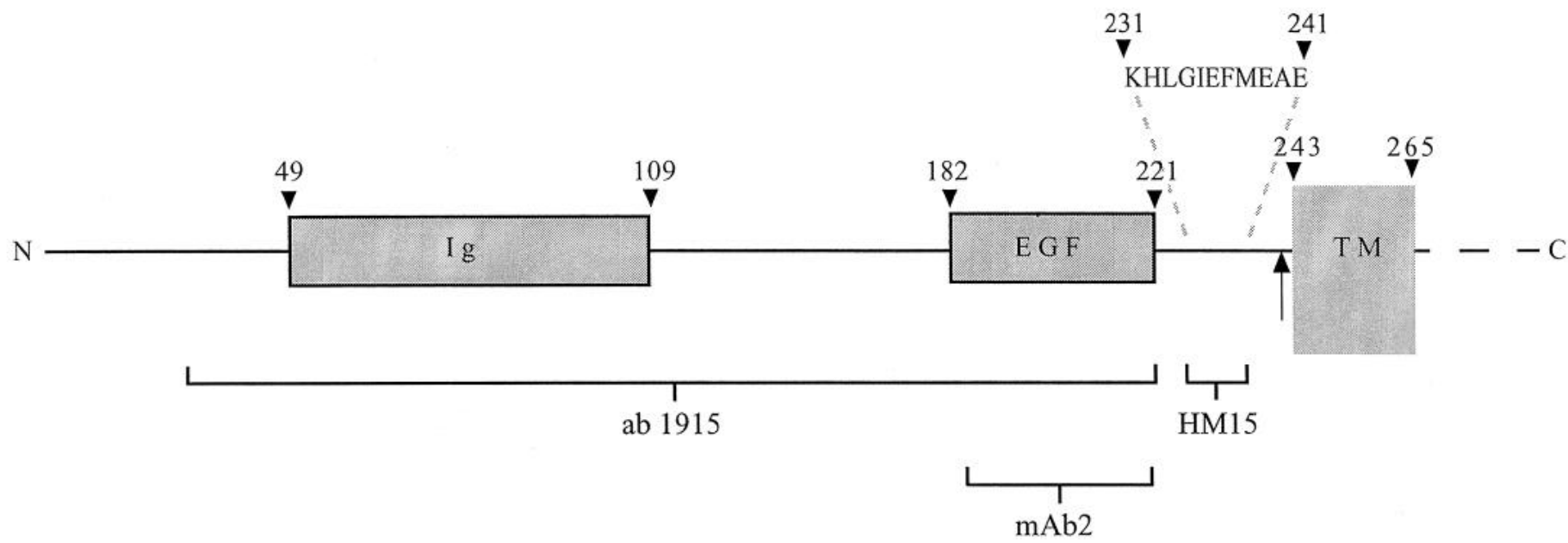

Figure 1. The extracellular domain structure of ARIA. The Ig-like, EGF-like, and transmembrane (TM) domains are represented by shaded boxes. The numbered arrowheads correspond to the relative positions of amino acid residues predicted by human NDF $\beta 1$, clone P13 (Wen et al., 1994). The amino acid sequence (KHLGIEFMEAE) in the juxtamembrane stretch, which specifies the " 1 " subtype of both $\alpha$-/and $\beta$ - isoforms of NDF, is shown expanded above the diagram. The arrow indicates adjacent basic amino acids which may be a cleavage site that releases soluble ARIA from the membrane-bound precursor. The location of antibody epitopes, as determined by ELISA and BIAcore binding assays, is depicted below the diagram (see Table 1).

predominantly in mesenchymal cells, whereas the $\beta$-isoforms exist mainly in the nervous system (Meyer and Birchmeier, 1994; Wen et al., 1994). The second splice site, which occurs in the juxtamembrane stretch several codons after the 6th cysteine of the EGF-like domain, specifies subtypes that are numbered 1 through 4 . RT-PCR analysis of 11 rat tissues has disclosed that the primary brain and spinal cord isoform of ARIA (NDF) is $\beta 1$ (Wen et al., 1994), as was the original ARIA isoform identified from a chick brain cDNA library (Falls et al., 1993). When expressed in bacteria or CHO cells, both the $\alpha$ and $\beta$-isoforms of the EGF-like domain exhibit high-affinity $\left(K_{D}\right.$ $\cong 10^{-9} \mathrm{M}$ ) binding to breast carcinoma cells and stimulates tyrosine phosphorylation of a $185 \mathrm{kDa}$ receptor tyrosine kinase (called p185 ${ }^{\text {erb32}}$, Holmes et al., 1992; or p185 1994), although the $\beta$-isoforms may have an order of magnitude higher potency than the $\alpha$-isoform (Wen et al., 1994). A diagram of the extracellular domain structure of the $\beta 1$ isoform of rat ARIA is depicted in Figure 1.

If ARIA is to be responsible for regulating the distribution, number, and maturation of AChRs at skeletal neuromuscular junctions, it must be present in nerve terminals soon after nervemuscle contact is established. In the studies described here, we have determined that ARIA-like immunoreactivity is present at the neuromuscular junction, both in the adult and during development. We present evidence that the bulk of ARIA at neuromuscular junctions is concentrated in motor nerve terminals, and that it arrives there by axonal transport rather than by being taken up from the extracellular space. Since this report was submitted, two papers have appeared that also show the presence of ARIA-like immunoreactivity at the adult rodent neuromuscular junction, using different antibodies (Chu et al., 1995; Jo et al., 1995). During the course of our studies, we found that ARIA was also present in nerve terminals at a variety of central, noncholinergic synapses.

\section{Materials and Methods}

Recombinant NDF protein production. The following recombinant proteins were produced in $E$. coli: human met-NDF- $\alpha 1_{14-249}$, expressed from codon positions 14-249 of human clone P1 (Wen et al., 1994); human met-NDF- $\alpha 2_{14-241}$ and met-NDF- $\alpha 2_{177-246}$ expressed from codon positions 14-241 and 177-246, respectively, of the human cDNA clone 43 (Wen et al., 1994); met-NDF- $\beta 1_{14-246}$ and met-NDF- $\beta 1_{177-246}$ expressed from codon positions 14-246 and 177-246, respectively, of the human cDNA clone P13 (Wen et al., 1994); and rat met-NDF- $\alpha 2_{14-241}$, expressed from codon positions 14-241 of the rat cDNA clone 19 (Wen et al., 1994). The extra methionine residue (met) at the $\mathrm{N}$-terminal of these proteins was added as the initiation site for protein translation. The recombinant proteins were purified to greater than $98 \%$ homogeneity by subjecting a clarified $E$. coli lysate to anion exchange, cation exchange, hydrophobic interaction, and hydroxyapatite column chromatography. These proteins stimulated MDA-MD-453 cell p185 rosine phosphorylation at concentrations as low as $5 \mathrm{ng} / \mathrm{ml}$.

Antibody production. Two polyclonal antibodies (1915 and HM15) and a monoclonal antibody (mAb2) were used for the studies described here. The brackets at the bottom of Figure 1 show the region of ARIA recognized by these antibodies.

Antibody 1915 was produced by immunizing rabbits with $200 \mu \mathrm{g}$ human met-NDF- $\alpha 2_{14-241}$ emulsified in complete Freund's adjuvant and injected at multiple subcutaneous sites. At 4 week intervals, the rabbits were boosted with multiple subcutaneous injections of $200 \mu \mathrm{g}$ antigen emulsified in incomplete Freund's adjuvant. Sera were collected by ear vein bleed $10 \mathrm{~d}$ after each injection and evaluated for immunoreactivity by ELISA, using human met-NDF- $\alpha 2_{14-241}$ as the capture antigen. AntiNDF antibodies were purified by affinity chromatography using an Actigel ALD kit, per manufacturer's recommendations (Sterogene Bioseparations, Arcadia, CA). The affinity gel was made by coupling $2 \mathrm{mg}$ of human met-NDF- $\alpha 2_{14-241}$ to $3 \mathrm{ml}$ of monoaldehyde-agarose; unreacted aldehyde groups were deactivated with $0.1 \mathrm{M}$ ethanolamine. Five milliliters of the antiserum was passed through a $1 \times 10 \mathrm{~cm}$ column containing the affinity gel. The column was washed with $50 \mathrm{ml}$ of phosphate-buffered saline (PBS) and eluted with $3 \mathrm{~mm} \mathrm{MgCl}_{2}, 80 \mathrm{~mm}$ Hepes, pH 6.0, 25\% ethylene glycol. The eluted antibodies were dialyzed overnight against PBS at $4^{\circ} \mathrm{C}$ and concentrated in a Centriprep unit (Amicon, Beverly, MA) to approximately $1 \mathrm{mg} / \mathrm{ml}$.

Antibody HM15 was produced by immunizing rabbits with an 11 amino acid synthetic peptide, KHLGIEFMEAE, which corresponds to the juxtamembrane sequence that identifies the $\beta 1$ isoform predicted from human (Holmes et al., 1992), bovine (Marchionni et al., 1993), and rat (Wen et al., 1994) cDNA clones homologs of ARIA (Falls et al., 1993; see Fig. 1). The same sequence also identifies the $\alpha 1$ isoform of rat NDF (Wen et al., 1994); thus, the sequence defines the " 1 " subtype of both of the major isoforms. A $1 \mathrm{mg} / \mathrm{ml}$ solution of the peptide was conjugated to Keyhole Limpet Hemocyanin (KLH) using the crosslinking reagent sulfo-MBS (Pierce, Rockford, IL), according to manufacturer's instructions. After desalting by gel filtration on a PD-10 column (Bio-Rad, Hercules, CA) and lyophilization, two rabbits were 
immunized with $100 \mu \mathrm{g}$ peptide : KLH emulsified in complete Freund's adjuvant, followed by monthly boosts of $50 \mu \mathrm{g}$ peptide : KLH emulsified in incomplete Freund's adjuvant (Cocalico Biologicals, Reamstown, PA). Monthly ear vein bleeds were screened by ELISA using the synthetic peptide as capture antigen. Serum from the rabbit with the higher titer (HM15) was affinity purified over a peptide : ovalbumin: Sepharose affinity column in $10 \mathrm{mM}$ Tris, $\mathrm{pH}$ 7.4. After extensive washing in 0.5 $\mathrm{M} \mathrm{NaCl}, 10 \mathrm{~mm}$ Tris, $\mathrm{pH} 7.4$, a $0.1 \mathrm{~m}$ glycine, $\mathrm{pH} 2.5$ step was used to elute fractions containing $1 / 10$ volume $0.4 \% \mathrm{NaN}_{3}, 1.0 \mathrm{M}$ Tris, pH 8.0. Iligh titer fractions, as determined by ELISA, were pooled, aliquoted, and stored at $4^{\circ} \mathrm{C}$.

MAb2 was produced against the EGF-like domain of the $\beta$-isoform of human NDF, in a modification of an immunosuppression procedure developed previously (Matthew and Sandrock, 1987). The immunizations were designed to suppress immunity toward $\alpha$-specific epitopes so as to favor the production of antibodies against $\beta$-specific epitopes. Details of the immunization procedure will be published elsewhere. In brief, six 8 week old female Balb/c mice (Charles River Laboratories, Wilmington, MA) were injected on two separate occasions (at 8 week intervals) with intraperitoneal injections of $50 \mu \mathrm{g}$ of recombinant human met-NDF- $\beta 1_{177-246}$, that had becn conjugated to glutardialdehydeactivated silicate particles (Boehringer Mannheim, Indianapolis, IN) per manufacturer's instructions. Three weeks after each immunization with NDF $\beta 1$, the mice were injected intraperitoneally with recombinant human met-NDF- $\alpha 2_{177-241}$ (similarly conjugated to glutardialdehyde-activated silicate particles) that were followed by three daily intraperitoneal injections of the immunosuppressive agent, cyclophosphamide (Sigma), at a dose of $100 \mathrm{mg} / \mathrm{kg}$ in PBS. Four days after a final boost with 100 $\mu \mathrm{g}$ of silica-conjugated human met-NDF- $\beta_{177-228}$, the spleens of the two mice with the highest anti-NDF $\beta$ titers were fused with NS1 myeloma cells, using PEG 1500 (Boehringer Mannheim), as previously described (Matthew and Sandrock, 1987). Hybridoma supernatants were screened by ELISA, using recombinant human met-NDF- $\beta_{177-228}$ as capture antigen. Of the seven antibodies obtained by the fusion of these two spleens, five displayed higher affinity binding to $\beta$ rather than $\alpha$-isoforms of the EGF domain of NDF, by ELISA. One of these, called $\mathrm{mAb} 2$, has been used for immunoblotting experiments in this study.

MAb2 did not stain fixed tissues. When we attempted to stain nmjs in unfixed tissues, structures that resembled motor nerve terminals were observed, but we could not be certain because the addition of detergent to unfixed tissue removed AChRs. Bungarotoxin, therefore, could not be used as an independent marker of motor endplates. Similar results were obtained with other monoclonal antibodies directed against the ARIA protein. Several anti-EGF domain monoclonal antibodies, including mAb2, did stain the cytoplasm of motor neuron cell bodies in unfixed tissue sections (dalid not shown).

ELISA. Polystyrene wells of 96-well ELISA plates were coated with synthetic peptide or $E$. coli-derived NDF isoforms at a concentration of 0.1 or $0.5 \mu \mathrm{g}$ per well in $\mathrm{Na}_{2} \mathrm{CO}_{3} / \mathrm{NaHCO}_{3}$ buffer, $\mathrm{pH} 9.6$. After blocking with $5 \%$ BSA or nonfat dry milk in PBS, the wells were incubated with hybridoma culture supernatant or affinity purified polyclonal antibodies (diluted with PBS) for $2 \mathrm{hr}$ at room temperature. The wells were washed with PBS or with KPL wash solution (KPL, Gaithersburg, MD), then incubated with a 1:1000 dilution of secondary antibody in PBS for one hour at room temperature. In some experiments, the secondary antibody was goat anti-mouse IgG conjugated to horseradish peroxidase (Boehringer Mannheim). In other experiments, the secondary antibody was either goat anti-mouse IgG or goat anti-rabbit IgG conjugated to alkaline phosphatase (Cappel, Durham, NC). After washing the wells four times with PBS or KPL wash solution, the plates were developed with ABTS substrate solution (KPL) in the case of HRP-conjugated secondary antibodies or with phosphatase substrate solution (Sigma) in the case of alkaline phosphatase-conjugated secondary antibodies. The plates were read on an ELISA reader at $405 \mathrm{~nm}$.

BIAcore analysis. Real-time biospecific interaction analysis, from Pharmacia Biosensor AB (Uppsala, Sweden), based on Surface Plasmon Resonance (SPR) (Malmborg et al., 1992), was used to characterize the binding specificitics of antibody 1915 . Recombinant $E$. coli-derived NDF proteins were covalently coupled to the sensor chip CM5 via the primary amine group. The immobilization was performed at a flow of $5 \mu \mathrm{l} / \mathrm{min}$ in $\mathrm{HBS}$ (150 $\mathrm{mm} \mathrm{NaCl}, 3.4 \mathrm{~mm}$ EDTA, $0.05 \%$ BIAcore surfactant $\mathrm{P}-20,10 \mathrm{~mm}$ Hepes, $\mathrm{pH} 7.4$ ). The carboxylated matrix of the sensor chip was first activated with a $40 \mu \mathrm{l}$ injection of a 1:1 mixture of EDC ( $400 \mathrm{~mm} N$-ethyl- $N$-(dimethylamine-propyl)-carbodiimide in water, Pharmacia) and NHS (100 $\mathrm{mm} N$-hydroxysuccinimide in water,
Pharmacia). Recombinant NDF was immobilized onto the sensor by injecting $65 \mu \mathrm{l}$ of a $50 \mu \mathrm{g} / \mathrm{ml}$ solution in $10 \mathrm{~mm}$ sodium acetate, $\mathrm{pH}$ 4.0. The excess reactive groups of the sensor chip were deactivated with an injection of $50 \mu \mathrm{l}$ of $1 \mathrm{~m}$ ethanolamine hydrochloride (Pharmacia). Each analysis cycle included an injection of $20 \mu \mathrm{l}$ of affinity purified antibody 1915, followed by an injection of $10 \mu \mathrm{l}$ of $10 \mathrm{~mm}$ $\mathrm{HCl}$ for regeneration of the chip. The binding of antibody changed the SPR, which was measured in Resonance Units (RU).

Animals and surgery. CD rats (Charles River Laboratories) were used for all experiments. Adult rats were female, weighing 300-400 gm. Prior to intracardiac perfusion or surgery, the animals were anesthetized with pentobarbital at doses of $20-50 \mathrm{mg} / \mathrm{kg}$ until general anesthesia was achieved (verified by testing for the absence of a corneal reflex). Using aseptic technique, the sciatic nerve was exposed at the level of the upper thigh, after shaving and disinfecting the skin of the proximal hind limb with $70 \%$ ethanol. Sciatic nerve transections were performed by removing a $0.5 \mathrm{~cm}$ segment of the nerve. In the case of colchicine cuff application, the epineurial sheath of the nerve was trimmed with microdissecting scissors under a dissecting microscope. A $1 \times 0.5 \mathrm{~cm}$ piece of Whatman filter paper was soaked in $10 \mathrm{~mm}$ colchicine (Sigma) in PBS before bcing wrapped around the nerve in the region of the epineurial fenestrations. In control experiments, the filter paper was soaked in PBS alone. The surgical wound was closed with skin staples, and the animals were kept warm under an infrared lamp and carefully monitored until fully recovered from anesthesia. All surgical procedures and animal handling were performed in accordance with Harvard Medical School guidelines for animal care.

Tissue immunoblots. Adult rats were sacrificed by $\mathrm{CO}_{2}$ inhalation, and the cerebellum, spinal cord, gastrocnemius/soleus muscles, and liver were immediately dissected and frozen on dry ice. The tissues were homogenized in 5 volumes $(\mathrm{w} / \mathrm{v})$ of ice-cold $\mathrm{Ca}^{2+}, \mathrm{Mg}^{2+}$-free PBS containing leupeptin $(1 \mu \mathrm{g} / \mathrm{ml})$, pepstatin $(1 \mu \mathrm{g} / \mathrm{ml})$, EDT $\Lambda(1 \mu \mathrm{mm})$, and Pefabloc SC (1 mM, Boehringer-Mannheim). A $1 \mathrm{ml}$ aliquot of each tissue homogenate was mixed with an equal volume of $2 \times$ Laemmli sample buffer (final concentrations: $3 \% \mathrm{w} / \mathrm{v}$ SDS; $10 \% \mathrm{v} / \mathrm{v}$ glycerol; $0.005 \% \mathrm{w} / \mathrm{v}$ bromphenol blue in $62.5 \mathrm{~mm}$ Tris, $\mathrm{pH} 6.8$ ), containing 50 $\mathrm{mm}$ dithiothreitol (DTT), and warmed to $100^{\circ} \mathrm{C}$ for $5 \mathrm{~min}$ before being stored at $-80^{\circ} \mathrm{C}$ until use. Protein concentrations were determined on the remainder of each tissue homogenate with the Bio-Rad Protein Assay, per manufacturer's recommendations. Tissue samples were normalized for protein concentrations, electrophoresed in $10 \%$ polyacrylamide-SDS gels, and transferred onto Immobilon PVDF transfer membranes (Millipore, Bedford, MA). The membranes were blocked with $10 \%$ nonfat dry milk in Tris-buffered saline (TBS), containing $0.1 \%$ Tween-20 (TBS-0.1\% T) for $1 \mathrm{hr}$, washed with three 5 min exchanges of TBS-0.1\% T, and incubated for $12-16$ hr at $4^{\circ} \mathrm{C}$ with affinity purified antibodies 1915 or HM15 (diluted 1:1000), or mAb2 (hybridoma culture supernatant, diluted $1: 5$ in TBS). After washing with three $5 \mathrm{~min}$ exchanges of TBS- $0.1 \% \mathrm{~T}$, the membranes were incubated in HRP-conjugated affinity purified goat anti-rabbit IgG or goat anti-mouse IgG (Cappel), diluted 1:4000 in TBS- $0.1 \% \mathrm{~T}$ containing $10 \%$ rat serum for $1 \mathrm{hr}$ at room temperature. The membranes were then washed with three 5 min incubations in TBS- $0.3 \% \mathrm{~T}$, followed by three more $5 \mathrm{~min}$ washes with TBS-0.1\% T, then incubated for 1 min with ECL detection reagents $\left(0.125 \mathrm{ml} / \mathrm{cm}^{2}\right.$, Amersham, Arlington Heights, IL), before being drained, wrapped in plastic wrap, and exposed to Reflection film (Du Pont-NEN, Boston, MA) for $15 \mathrm{sec}$ to $5 \mathrm{~min}$.

Immunoblots of transfected COS cells. COS-7 cells were grown to $70 \%$ confluence in $100 \mathrm{~mm}$ tissue culture Petri dishes. The cells were transfected with $10 \mu \mathrm{g}$ of either a rat NDF $\beta$ IcDNA clone that had been inserted in the pJT-2 eukaryotic expression vector under the control of the SV40 early promoter, or the pCH1 10 eukaryotic assay vector (which contains the lac-Z gene under the control of the same promoter) (Pharmacia), using the DEAE-dextran-chloroquine method (Sambrook et al., 1989). After shocking the cells with DMSO for $3 \mathrm{~min}$ at room temperature, the cells were returned to the incubator in OptiMEM-COS medium (GIBCO-BRL). Twenty-four hours later, the cultures were rinsed twice with PBS and the cells were scraped off the dish into 1.5 $\mathrm{ml}$ of Laemmli SDS-PAGE sample buffer (3\% w/v SDS; $10 \% \mathrm{v} / \mathrm{v}$ glycerol; $0.005 \% \mathrm{w} / \mathrm{v}$ bromphenol blue in $62.5 \mathrm{~mm}$ Tris, $\mathrm{pH} 6.8$, containing $50 \mathrm{~mm}$ DTT) and triturated. The samples were heated to $100^{\circ} \mathrm{C}$ for 5 min prior to electrophoresis in an $8 \%$ polyacrylamide gel. After electrophoretic transfer, Immobilon PVDF membranes were blocked, incubated with affinity purified antibody 1915 and further processed as described above for tissue immunoblots. 
Table 1. Sunnuary of antibody binding specificities

Recombinant NDF proteins

\begin{tabular}{|c|c|c|c|c|c|c|}
\hline Antibodies & $\begin{array}{l}\text { Human } \alpha 1 \\
(14-249)\end{array}$ & $\begin{array}{l}\text { Human } \alpha 2 \\
(14-241)\end{array}$ & $\begin{array}{l}\text { Human } \alpha 2 \text {, } \\
\text { EGF domain } \\
(177-241)\end{array}$ & $\begin{array}{l}\text { Human } \beta 1 \text {, } \\
(14-246)\end{array}$ & $\begin{array}{l}\text { Human } \beta 1 \text {, } \\
\text { EGF domain } \\
(177-246)\end{array}$ & $\begin{array}{l}\text { Rat } \alpha 2 \\
(14-241)\end{array}$ \\
\hline \multicolumn{7}{|l|}{ Polyclonal } \\
\hline 1915 & + & + & + & + & + & + \\
\hline HM15 & + & - & - & + & + & $\mathrm{nt}$ \\
\hline \multicolumn{7}{|l|}{ Monoclonal } \\
\hline $\mathrm{mAb} 2$ & $\mathrm{nt}$ & $\mathrm{nt}$ & + & $\mathrm{nt}$ & + & $\mathrm{nt}$ \\
\hline
\end{tabular}

Data summarize antibody binding specificities against $E$. coll-derived recombinant NDF proteins, as elucidated by ELISA (HM15 and $\mathrm{mAb} 2$ ) or BIAcore binding analysis (1915). +, significant antibody binding; -, no detectable binding; nt, not tested. Numbers in parentheses refer to codon positions of human NDF cDN $\Lambda$ clone 43 (Wen et al., 1994; see also Fig. 1 ).

Immunohistochemistry. Adult and postnatal rats were anesthetized with pentobarbital as previously described and perfused through the heart with $4 \%$ paraformaldehyde in $0.1 \mathrm{M}$ phosphate buffer, $\mathrm{pH} 7.4$, at room temperature for $10 \mathrm{~min}$. Tissues were dissected and immersed in fixative for an additional hour at room temperature. In the case of embryos, the spinal column and hind limbs were dissected from freshly sacrificed animals and immersed in fixative for $1 \mathrm{hr}$ at room temperature. In all cases, the fixed tissues were rinsed in PBS, followed by equilibration for $12-16 \mathrm{hr}$ at $4^{\circ} \mathrm{C}$ in $30 \%$ sucrose for cryoprotection; $10-14 \mu \mathrm{m}$ frozen sections were cut in a cryostat, and dried onto SuperfrostPlus glass slides (Fisher Scientific). After blocking for $30 \mathrm{~min}$ with dilution buffer $(0.5 \mathrm{M} \mathrm{NaCl}$ in $0.1 \mathrm{M}$ phosphate buffer, $\mathrm{pH} 7.4$, containing $10 \%$ goat serum, $0.1-0.3 \%$ Triton $\mathrm{X}-100$, and $0.1 \%$ sodium azide), the sections were incubated in primary antibody, diluted 1:300 in dilution buffer, for $12-16 \mathrm{hr}$ at room temperature in a humidified chamber. After rinsing with PBS, the sections were incubated in either Cy3-conjugated (Jackson Immunoresearch Labs,, West Grove, PA) or rhodamine-conjugated (Cappel) goat anti-rabbit antibodies, diluted 1:400 in dilution buffer (containing 10\% rat serum in the place of goat serum) for $1 \mathrm{hr}$ at room temperature. In all immunohistochemical experiments presented here, the primary antibody was either affinity purified antibody 1915 or HM15. In double-labeling experiments involving colocalization at adult neuromuscular junctions, fluorescein-conjugated $\alpha$-bungarotoxin (1:200 dilution, Molecular Probes, Eugene, OR) was included in the secondary antibody incubations in order to label AChRs. In other double-labeling experiments, anti-SV2 (hybridoma supernatant containing mouse monoclonal antibody $10 \mathrm{H}$, a gift of Dr. Kathy Buckley, Dept. of Neurobiology, Harvard Medical School, diluted 1:10) or anti-neurofilament (mouse monoclonal antibodies from clones NR4 and NN18, Boehringer-Mannheim, diluted 1:5) antibodies, were included in the primary antibody incubations, and fluoresceinconjugated goat anti-mouse Ig (diluted 1:200; Boehringer Mannheim) was included in the secondary antibody incubations. Some sections in each experiment were incubated without primary antibodies to control for nonspecific binding or cross-reactivity of the secondary antibodies. In addition, the specificity of affinity purified 1915 was confimed by absorbing the antibody to recombinant human met-NDF- $\alpha 2_{14-241}(100$ $\mu \mathrm{g} / \mathrm{ml}$ ) for $2 \mathrm{hr}$ at room temperature prior to use. Similarly, affinity purified HM15 was absorbed with $10 \mu \mathrm{g} / \mathrm{ml}$ of the synthetic peptide (KHLGIEFMEAE) used to raise the antibody. In each case, the staining pattern of the primary antibody was abolished by preabsorption with its corresponding antigen.

\section{Results}

Antibody characterization. The antibodies were characterized by ELISA or BIAcorc binding assays using rccombinant, E. coliderived human and rat NDF proteins as capture antigen (Table 1). Most of the experiments reported in this article were performed with antibody 1915, an affinity purified, polyclonal antibody raised against virtually the entire extracellular domain of recombinant human proNDF $\alpha 2$ (see Fig. 1). We feel that this antibody primarily recognizes the EGF domain of ARIA for the following reasons. Antibody 1915 binds to recombinant human $\alpha 1$, human $\alpha 2$, human $\beta 1$, as well as rat $\alpha 2$ homologs of ARIA (Table 1). Moreover, the antibody binds to $\alpha$ and $\beta$ NDF fragments composed of solely the EGF-like domain (Table 1), and BIAcore studies indicate that the binding affinity for $\alpha$ - and $\beta$ isoforms of NDF is roughly equivalent (data not shown). Thus, antibody 1915 appears to bind to the region of the EGF-like domain of NDF that is common to all isoforms of this protein.

We have found that an $E$. coli-derived protein consisting of solely the EGF-like motif of human NDF is sufficient for inducing AChR incorporation in chick skeletal muscle cells, as well as in stimulating tyrosine phosphorylation of p185 in L6 cells-both in the nanomolar range. Antibody 1915 inhibits ARIA's stimulation of p 185 tyrosine phosphorylation in rat L6 muscle cells by at least $50 \%$ (Loeb and Fischbach, in press). Thus, antibody 1915-because of epitopes in the common region of the EGF-like domain-probably binds to all functional rat and human homologs of ARIA.

ELISA experiments have confirmed that HM15, a polyclonal antibody generated against a synthetic peptide corresponding to the juxtamembrane sequence that specifies the " 1 " subtype of both $\alpha$ and $\beta$ ARIA isoforms, binds only to $\alpha 1$ and $\beta 1$ isoforms of recombinant NDF (Table 1). No binding was detected to isoforms of the " 2 " subtypes (Table 1). In our studies, we assume that HM15 is primarily binding to $\beta 1$ isoforms, since $\alpha$-isoforms are rare in the nervous system (Wen et al., 1994).

We also employed a monoclonal antibody, mAb2, that was raised against the EGF $\beta$-fragment (amino acids 177-228) of recombinant human NDF. Whereas MAb2 binds to the EGF-like domain of both $\beta 1$ and $\alpha 2$ human NDF isoforms (Fig. 1, Table 1 ), we have found that antibody binding to $\beta$-isoforms is more avid than binding to $\alpha$-isoforms of NDF (data not shown). Thus, mAb2 may bind to the EGF-like domain between the 5 th and 6 th cysteine residues where the $\alpha$ - and $\beta$-isoforms diverge in sequence.

Whereas Table 1 summarizes antibody binding specificities against $E$. coli-derived human and rat homologs of recombinant ARIA, other experiments have demonstrated specific binding to comparable $\mathrm{CHO}$ cell-derived preparations (unpublished observations). Thus, the addition of carbohydrate moieties by eukaryotic cells does not eliminate the recognition of ARIA by these antibodies.

Antibody 1915 was used to probe Western blots of whole extracts of COS cells that had been transfected with plasmids 

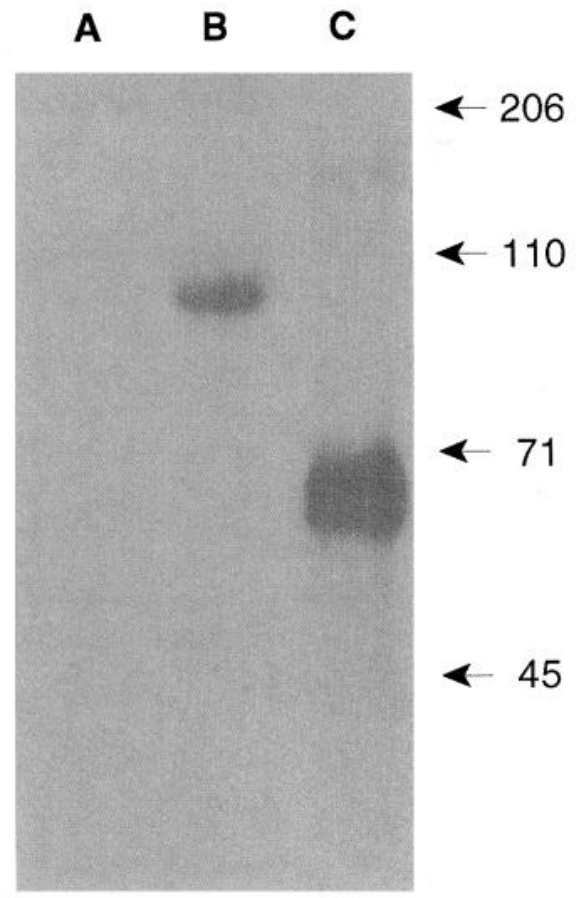

Figure 2. Western blots, probed with antibody 1915 , of whole extracts of $\operatorname{COS}$ cells that had been transfected with a eukaryotic expression vector containing the lac- $Z$ gene (lane $A$ ), a rat NDF $\beta$ la cDNA (lane $B$ ), and a human NDF $\alpha 2 \mathrm{c}$ cDNA (lane $C$ ). The positions of molecular weight markers are shown with arrows.

containing either full length proNDF constructs or an irrelevant gene, $\beta$-galactosidase. The cytoplasmic tail of rodent proNDFs contains three major splice variants of 157,196 , and 374 amino acid lengths, called a, b, and c, respectively (Wen et al., 1994). A single band of $M_{r} 85 \mathrm{kDa}$ is present in extracts of $\beta 1$ a-transfected cells (Fig. 2, lane B). In extracts of COS cells transfected with human $\alpha 2 \mathrm{c}$, a single broad band of $M_{r} 65-70 \mathrm{kDa}$ was evident (Fig. 2, lane C). The difference in the relative mobility of these bands is expected, considering the different lengths of the predicted cytoplasmic domains of these two forms (213 amino acids). No band at $45 \mathrm{kDa}$, the expected size of the glycosylated, extracellular portion of ARIA (which is presumed to be cleaved from the transmembrane precursor) was found associated with the cells. A $45 \mathrm{kDa}$ bioactive form has been found in concentrates of medium conditioned by the transfected COS cells (unpublished observations). As expected, antibody 1915 does not recognize a protein in an extract of COS cells transfected with $\beta$-galactosidase (Fig. 2, lane A).

Localization at the neuromuscular junction. Figure $3 A$ shows a region of adult rat soleus muscle, cut in cross-section, that has been stained with fluorescein conjugated $\alpha$-bungarotoxin. A linear, sometimes cup-shaped staining pattern, typical of $\mathrm{AChR}$ clusters lining the primary postsynaptic folds of nmjs, is apparent. The same section, stained with antibody 1915 followed by a Cy3-conjugated secondary antibody (Fig. $3 B$ ), reveals intensely fluorescent structures that seem to fit into the AChR-rich gutters of the endplate. This appearance strongly suggests that the anti-ARIA antibody stains motor nerve terminals. Every neuromuscular junction localized with $\alpha$-bungarotoxin, in several different adult rat muscles, contained similarly stained profiles of 1915 immunoreactivity.

Further evidence that antibody 1915 stained motor nerve ter- minals was obtained by cutting the sciatic nerve $2 \mathrm{~d}$ before sacrificing the animal for histological processing. Denervation resulted in the loss of most of antibody 1915 immunoreactivity at soleus muscle nmjs (Fig. $3 C, D$ ). The rapid disappearance, after denervation, of the bulk of ARIA-like immunoreactivity at neuromuscular junctions is consistent with the notion that ARIA is concentrated in motor nerve terminals.

Anti-ARIA staining did not disappear entirely after denervation (Fig. 3D). 1915-immunoreactivity was detectable at vacated endplates, but it was much less intense and seemed to be distributed over a greater area. Since similar results were obtained in muscles that had been denervated for $7 \mathrm{~d}$ (data not shown), the low level staining that persists at nmjs after denervation is unlikely to be debris from degenerating nerve terminals. We favor the view that the residual staining at denervated endplates represents ARIA molecules that have been deposited in the synaptic extracellular matrix after being released from motor nerve terminals. Preliminary ultrastructural studies with a different anti-ARIA antibody have directly demonstrated the presence of ARIA-like immunoreactivity in the synaptic basal lamina of neuromuscular junctions in chick embryos (Goodearl et al., 1994).

We have not detected staining at neuromuscular junctions with antibody HM15 - even in the same experiments in which HM15 stained other areas of the nervous system (see below). Thus, $\beta 1$ isoforms are either not a large fraction of the total ARIA present in peripheral motor nerve terminals, or nerve terminal $\beta 1$ ARIA has been processed in such a way that is not recognized by HM15. We favor the latter possibility because spinal cord immunoblots with HM15 are qualitatively similar to those with 1915 (see below and Fig. 8).

Localization in motor neuron axons and cell bodies. In some sections of adult rat skeletal muscle, 1915-immunoreactive preterminal axons were visible (Fig. $4 A$ ). These intramuscular axons branched and coursed between the muscle fibers. No ARIAlike immunoreactivity was detected in the more proximal motor nerve axons of peripheral nerve. Motor neuron cell bodies were clearly stained with antibody 1915 (Fig. 4B). The antigen appeared to be nonuniformly distributed throughout the cytoplasm of large neurons in the anterior horn. In addition to the diffuse cytoplasmic staining, small intensely stained spots were distributed in the neuropil and around the perimeter of the anterior horn cell bodies (Fig. 4B). As discussed below, these bright spots probably represent synaptic boutons.

Axonal ARIA might have been undetectable because it is rapidly transported between the perikaryon and the nerve terminal. To test this possibility, colchicine-a drug that inhibits fast axonal transport-was applied to a segment of sciatic nerve. Prior to application, the epineurium was trimmed to improve penetration of the drug into the nerve. Figure $4 C$ shows a longitudinal section of a sciatic nerve segment that had been exposed to colchicine for $16 \mathrm{hr}$ in vivo. Thin, unbranched streaks of fluorescence were evident near the center of the treated nerve (arrows). The simplest interpretation is that these streaks represent axons. Some of the streaks appeared to have blunted or swollen ends consistent with the accumulation of axoplasm. Similar shapes were not seen at more proximal or more distal sites within the treated nerve, in the untreated contralateral control nerve, or in nerves treated with vehicle (Fig. 4, inset). Intense staining was present along the nerve periphery in structures that appeared to be swollen, degenerating axons and myelin fragments; this region was likely damaged by the surgery and/or high colchicine concentrations. 

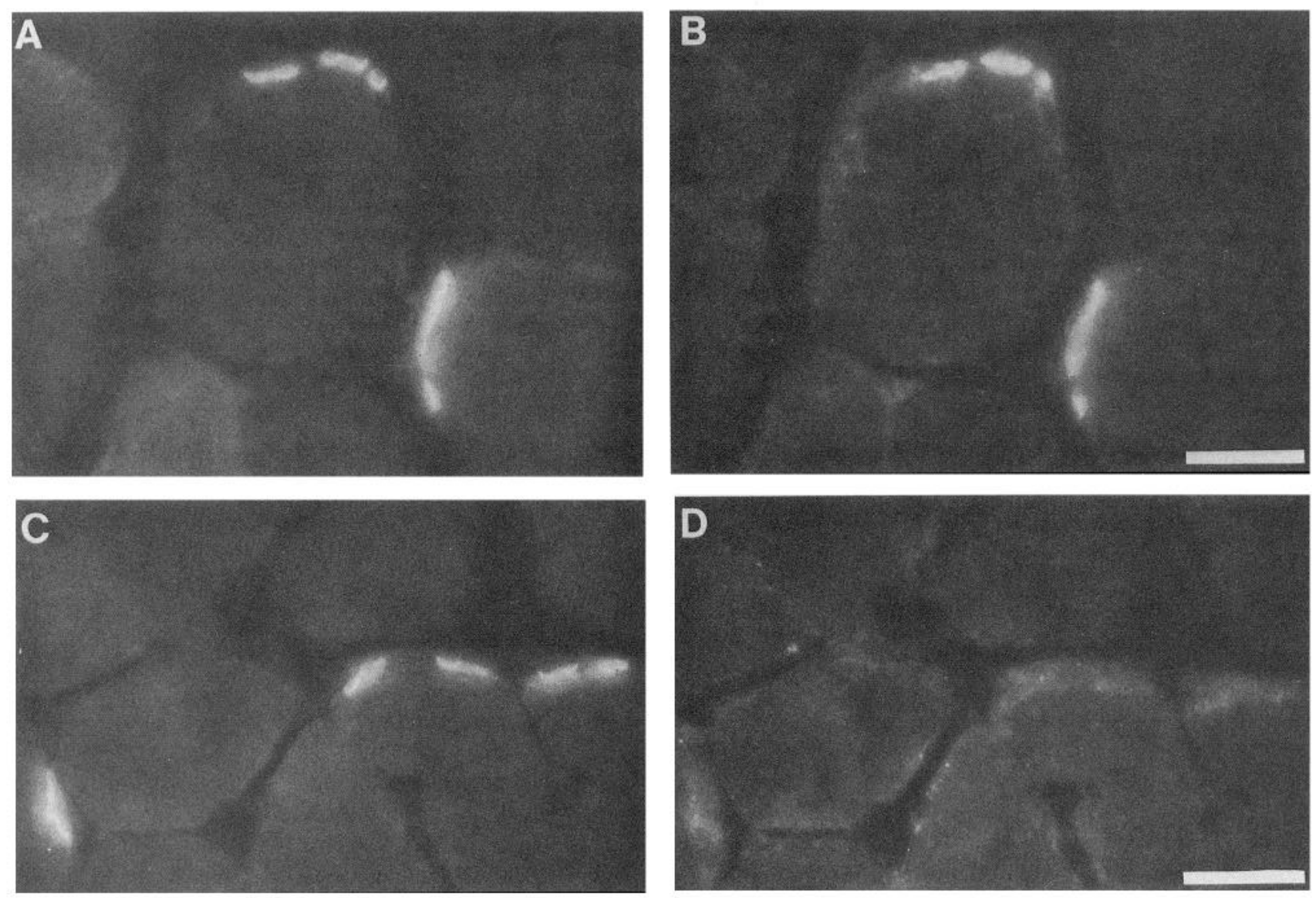

Figure 3. ARIA-like immunoreactivity at adult rat neuromuscular junctions. Upper panels ( $A$ and $B$ ) show a section of soleus muscle with innervated endplates and the lower panels $(C$ and $D)$ show a section with denervated endplates. The distribution of ACh receptors, labeled with fluorescein- $\alpha$ bungarotoxin, is shown in the panels on the left ( $A$ and $C$ ). The distribution of ARIA-like immunoreactivity, labeled with antibody 1915 followed by Cy3-conjugated secondary antibody, is shown in the panels on the right $(B$ and $D)$. Note the intense staining of intact nerve terminals $(B)$ in contrast to the faint residual staining in the region of vacated, denervated endplates $(D)$. Scale bar, $20 \mu \mathrm{m}$.

ARIA expression during development. Spinal cord from embryonic day 18 (E18), and hind limb muscles from E18, postnatal day 1 (P1), and P7 rats were stained with antibody 1915 . In these experiments, intramuscular nerve fibers and nerve terminals were labeled with presynaptic markers-anti-neurofilament and anti-SV2 antibodies. There was intense staining in E18 motor neurons (Fig. 5A, arrow). At this stage, there was staining above background in the intermediate gray matter, but it was less intense than that observed in the anterior horn. Staining was also evident within the adjacent dorsal root ganglion. In situ hybridization studies have shown that ARIA mRNA is abundant in E18 motor neurons and DRG neurons (Corfas et al., 1995).

Despite the intense staining of motor neuron cell bodies, we did not detect ARIA-like immunoreactivity within intramuscular nerve fibers in E18 embryos (Fig. 5B,C). Bright 1915 immunofluorescence was, however, evident in the motor nerve fibers of P1 animals. At this time, the ARIA-like immunoreactivity was located along the perimeter of myofibers in punctate or filamentous structures that were also stained with anti-neurofilament antibodies (Fig. 5D,E). In P7 muscle, 1915 staining was more intense and the nerve terminals appeared to be larger (Fig. $5 F, G)$. While there was good general correspondence between SV2 and ARIA-like immunoreactivity in early postnatal muscle, the overlap was not precise. A consistent finding was that ARIAlike immunoreactivity was more widespread than SV2 immu- noreactivity in developing muscle. This may reflect the fact that ARIA is released from motor nerve terminals and diffuses beyond its source. Alternatively, ARIA may be synthesized in developing muscle cells at low levels. A third possibility is that the SV2 staining pattern may underestimate the distribution of nerve terminals in early postnatal rats, when the concentration of synaptic vesicles may be below the detection limit of the antiSV2 antibody in some newly formed sprouts.

ARIA in central synapses. As noted above, punctate 1915 staining surrounded spinal cord motor neurons. The relationship between this staining pattern and the distribution of SV2 antigen (a constituent of synaptic vesicles) was examined in the spinal cord and in the cerebellar cortex. Figure 6 compares the pattern of anti-SV2 labeling (on the left) with that of anti-ARIA staining (on the right). In the cerebellum, antibody 1915 stains the synapse-rich molecular layer intensely. Staining in the granule cell layer is patchy and there was no staining in the white matter. In both the molecular layer and the granule cell layer, the correspondence between SV2 and ARIA localization is precise. This is evident at low power (panels $A$ and $B$ ), and is emphasized in the higher power views of the granule cell layer shown in panels $C$ and $D$. Thus, it is likely that staining in the granule cell layer resides in mossy fiber terminals rather than the granule cells themselves.

The correspondence between antibody 1915 and anti-SV2 

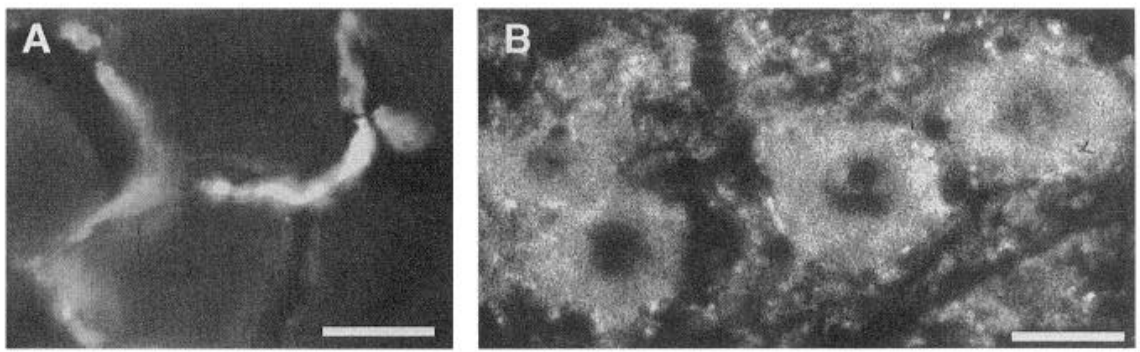

Figure 4. ARIA-like immunoreactivity in motor neurons and their axons. A cross-section of soleus muscle, in which a preterminal motor axon was cut longitudinally as it branched intramuscularly, is shown in $A$. The staining is diffuse where the axon leaves the plane of focus. A high power view of three motor neuron cell bodies labeled with antibody 1915 is shown in $B$. Note that the intracellular staining is not uniform. Note also the bright punctate staining in the surrounding neuropil that probably corresponds to presynaptic boutons. $C$ is a longitudinal section of sciatic nerve in the region where the epineurial sheath was trimmed and the nerve was surrounded by a colchicine-soaked filter paper cuff. The arrows point to numerous fine axons stained with antibody 1915 . The proximal and distal ends of the nerve segment are labeled. The inset shows a similarly stained longitudinal section of a control nerve which was surrounded by a filter paper cuff soaked with PBS, shown at about half the magnification. Damaged structures are stained in both colchicine and PBS-treated nerves, but axons are stained only in nerves treated with colchicine. Scale bars: $A$ and $B$, $20 \mu \mathrm{m} ; C, 100 \mu \mathrm{m}$.

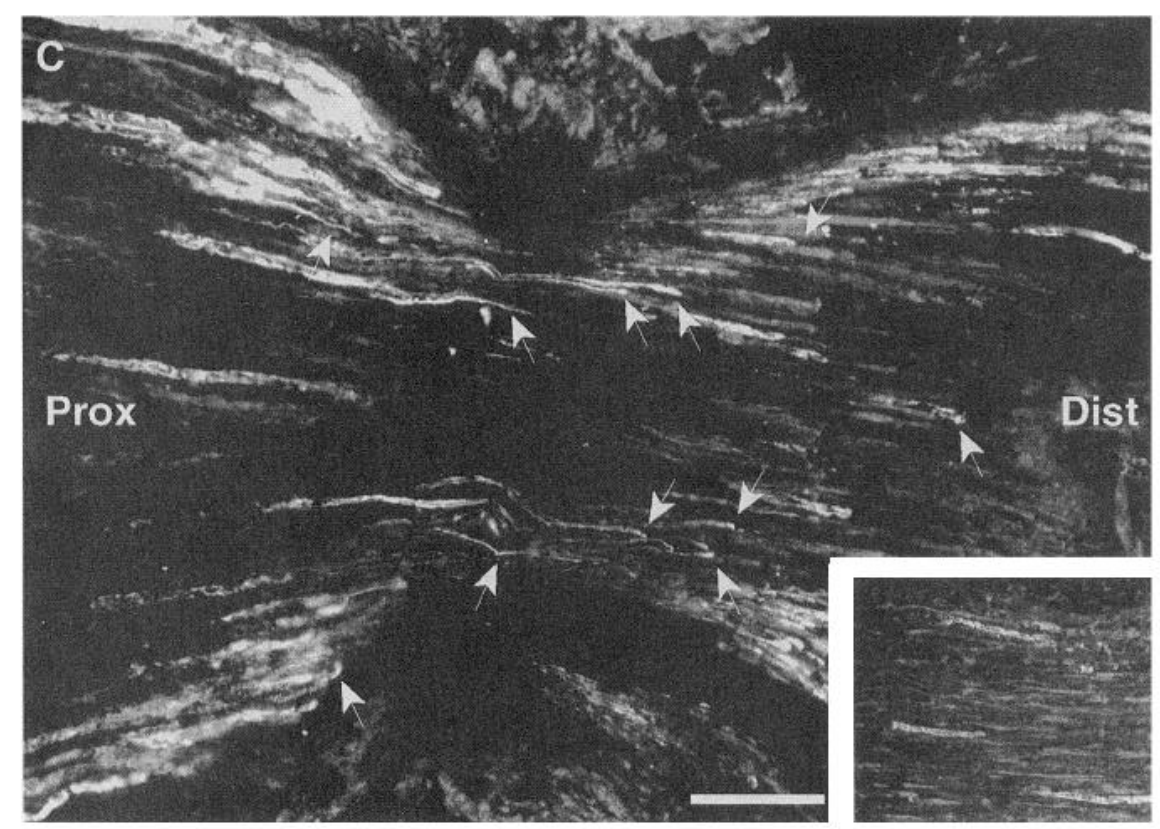

staining was also evident in the anterior horn of the spinal cord (panels $E$ and $F$ ). Motor neuron cell bodies and proximal dendrites were outlined by the dense plexus of synaptic boutons which were recognized by both anti-SV2 and 1915. The less intense but definite staining of the motor neuron cytoplasm with antibody 1915 can be compared to the lack of cytoplasmic staining with anti-SV2. Similar correspondence between anti-SV2 and antibody 1915 staining was seen in other regions of the CNS, but a systematic survey was not performed.

The dorsal horn of the spinal cord stains heavily with antibody 1915 (Fig. 7A). The staining pattern was consistent with the localization of ARIA in sensory synaptic terminals and, possibly, its release into the extracellular space. HM15, an antibody specific for $\beta 1$ isoforms of ARIA in the nervous system, provides an even more dramatic illustration of the concentration of ARIA in the sensory nerve terminals of the superficial layer(s) of the dorsal horn (Fig. $7 B$ ).

The ARIA family of proteins contains many alternatively spliced isoforms. It is unlikely that all nerve terminals contain the same isoforms. A striking example of antigen heterogeneity was found in adult dorsal root ganglia. Antibody 1915-a panARIA antibody-labeled all neurons in the ganglion (Fig. 7C), a finding consistent with the widespread distribution of 1915immunoreactivity in the dorsal horn of the spinal cord (Fig. 7A). In contrast, HM15, the $\beta 1$-specific antibody, labeled only the small neurons within adult DRG (Fig. 7D), and its staining pattern in the spinal cord was restricted to the most superficial laminae of the dorsal horn (Fig. 7B). Whether HM15 recognizes an amino acid sequence or a conformational determinant, it is clear that the antigen is restricted to a subset of sensory neurons and their terminals.

ARIA-like immunoreactive proteins in rat tissues. Figure 8 shows Western blots of adult rat spinal cord, muscle, and liver homogenates probed with antibodies 1915, HM15, and mAb2. In spinal cord, three principal bands of $M_{r} 45,72$, and $150 \mathrm{kDa}$ were detected by antibody 1915 and mAb2, both of which recognize the EGF-like domain of ARIA. Because all three proteins are also HM15-immunoreactive, they may all exist as the $\beta 1$ isoform. The band centered at $45 \mathrm{kDa}$, which was present in highest abundance, is identical to the size of ARIA purified from chicken brain (Falls et al., 1993). Thus, this protein probably corresponds to the glycosylated extracellular cleavage product of the transmembrane precursor. The $72 \mathrm{kDa}$ band probably represents the transmembrane precursor because it is in the size range of precursor NDF proteins expressed by COS cells (65$85 \mathrm{kDa}$; see Fig. 2). The $150 \mathrm{kDa}$ band is larger than any ARIA isoform predicted by the published cDNA sequences. Because it is labeled with three antibodies directed against different epitopes within and adjacent to the EGF-like domain, it is likely to be a member of the ARIA family of proteins.

No band was evident in homogenates of liver probed with antibodies 1915 or HM15 (Fig. 8), or mAb2 (data not shown). In muscle, two faint high molecular weight bands were detected by 1915 . The band at approximately $150 \mathrm{kDa}$ was also weakly recognized by $\mathrm{mAb} 2$, suggesting that it is immunologically related to the ARIA family of proteins. However, AChR inducing activity has never been found in extracts of skeletal muscle or liver. Moreover, these extracts do not promote p185 tyrosine 

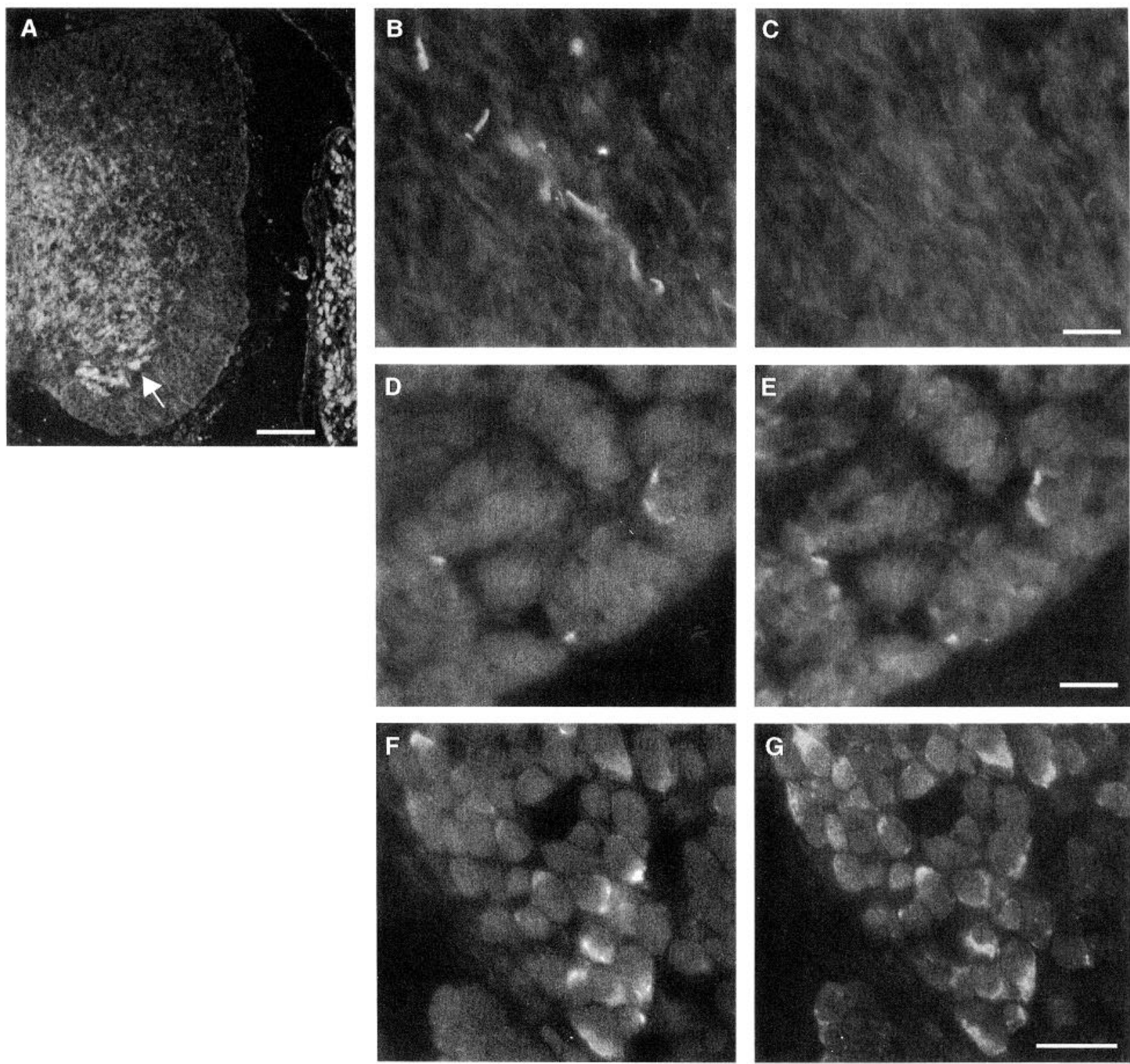

Figure 5. ARIA-like immunoreactivity in developing motor neurons. A cross-section of E18 rat spinal cord is shown in A. The arrow points to heavily stained motor neurons. Intense staining is also evident in DRG cells adjacent to the spinal cord. $B-G$ show sections of hindlimb muscle at E18 $(B, C), \mathrm{P} 1(D, E)$, and $\mathrm{P} 7(F, G)$. The panels on the left $(B, D, F)$ show the staining pattern of presynaptic markers (anti-neurofilament in $B$ and $D$; anti-SV2 in $F)$. The panels on the right $(C, E, G)$ show the staining pattern of antibody 1915 . No ARIA-like immunoreactivity was detected in motor axons on E18. Scale bars: $A, 300 \mu \mathrm{m} ; C, E, G, 20 \mu \mathrm{m}$.

phosphorylation in muscle membranes. Further studies are needed to define the epitopes recognized in skeletal muscle. ARIA mRNA has not been detected in rat muscle by RT-PCR (Wen et al., 1994).

\section{Discussion}

We conclude that ARIA is synthesized by motor neurons, actively transported down motor axons, and concentrated in motor nerve terminals. Our data support the hypothesis that ARIA, or a closely related molecule, participates in the accumulation of AChRs at nerve-muscle synapses. ARIA-like immunoreactivity was detected at neuromuscular junctions as early as the first postnatal day. Nerve-evoked and spontaneous synaptic potentials can be recorded in rodent intercostal muscle in E15 embryos (Dennis et al., 1981) and AChRs begin to accumulate at junc- tions at about the same time (Lupa and Hall, 1989). ARIA mRNA is detectable, by in situ hybridization, in motor neurons as early as E14 (Corfas et al., 1994), and we have shown that an ARIA-like protein exists in motor neuron cell bodies at E18, the only embryonic age examined. We were, however, unable to detect ARIA-like immunoreactivity at neuromuscular junctions at this time. This disparity between the onset of pro-ARIA protein synthesis in motor neurons and the detectability of ARIAlike immunoreactivity at motor nerve terminals may be the result of a delay imposed by processing and/or axonal transport requirements. It is also possible that ARIA is actually present in biologically significant amounts within motor nerve terminals as early as E15, but that its concentration is below the detection limit of our antibody.

We feel that the principal reagent used in this study, antibody 

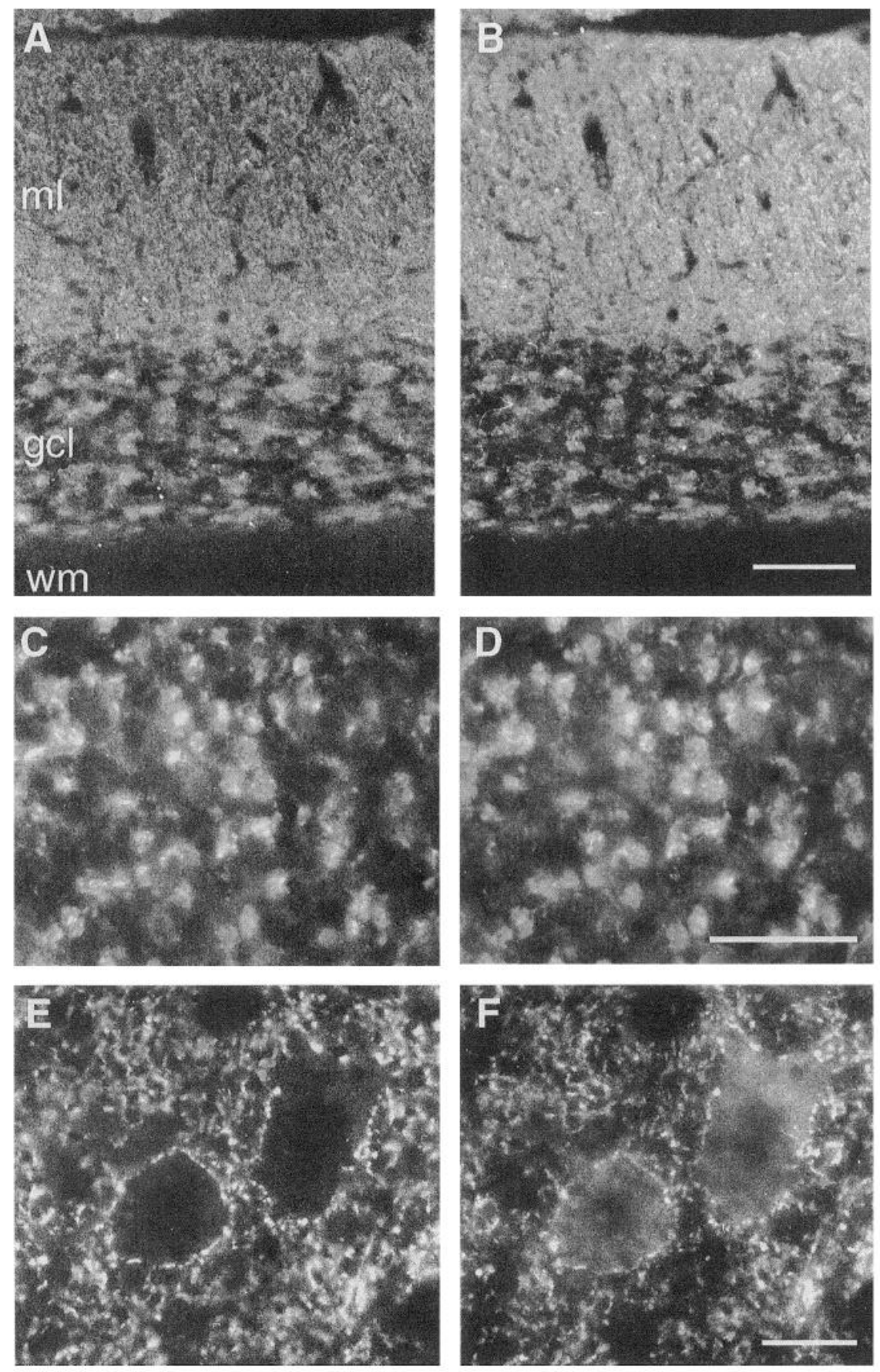

Figure 6. ARIA-like immunoreactivity is concentrated in interneuronal synaptic boutons. The pattern of SV2 staining $(A, C, E)$ is virtually superimposable on the pattern of antibody 1915 label in the cerebellum $(A-D)$ and spinal cord $(E, F)$. The amount of ARIAlike immunoreactivity in the synapserich molecular layer $(\mathrm{ml})$ is striking. Antibody 1915 stains mossy fiber endings in the granule cell layer $(\mathrm{gcl})$ rather than the granule cell bodies, as seen at high power in $C$ and $D$. There is no detectable ARIA-like immunoreactivity in the cerebellar white matter $(\mathrm{wm})$. Note that both antibody 1915 and antiSV2 stain the synaptic boutons which surround motor neuron cell bodies and proximal dendrites $(E, F)$; whereas only antibody 1915 stains the motor neuron cell bodies $(F)$. The reduced intensity of cell body staining in this figure compared to that of Figure $4 B$ is attributable to the difference in the plane of focus of these photomicrographs. Scale bars: $A$ and $B, 50 \mu \mathrm{m} ; C$ and $D, 40 \mu \mathrm{m} ; E$ and $F, 20 \mu \mathrm{m}$.
1915 , accurately reports the location of the major ARIA isoforms for the following reasons. In Western blots of whole COS cell extracts, the antibody recognizes a protein only in those cells that have been transfected with ARIA. In addition, spinal cord immunoblots probed with $\mathrm{mAb} 2$, a monoclonal antibody directed against the EGF-like domain, as well as HM15, a polyclonal antibody directed against the juxtamembrane stretch of $\alpha 1$ and $\beta 1$ isoforms, reveal the same proteins as those recognized by antibody 1915. Finally, there is excellent correspondence between the nerve terminals of cell types that are stained by antibody 1915 and those that show ARIA mRNA expression by in situ hybridization, in both the spinal cord and cerebellum (Chen et al., 1994; Corfas et al., 1995). Nevertheless, it is still possible that the lack of ARIA-like immunoreactivity in E18 nerve terminals reflects the presence of a biologically active isoform of ARIA that is not recognized by antibody 1915 .

Our results suggest that ARIA continues to accumulate in rat motor nerve terminals during the early postnatal period. This accumulation coincides with a "maturation" of AChRs at mammalian neuromuscular junctions, characterized by the replacement of AChRs composed of $\alpha_{2} \beta \gamma \delta$ subunits with those containing $\alpha_{2} \beta \epsilon \delta$ subunits (Gu and Hall, 1988; Witzemann et al., 1989). This change in subunit composition affects AChR channel properties (Mishina et al., 1986) and depends on nerve-derived factors (Schuetze and Vicini, 1984; Brenner et al., 1990). Because ARIA has been found to increase the synthesis of the $\epsilon$-subunit RNA in mouse myotube cultures (Martinou et al., 1991), an effect mimicked by no other candidate trophic factor, 

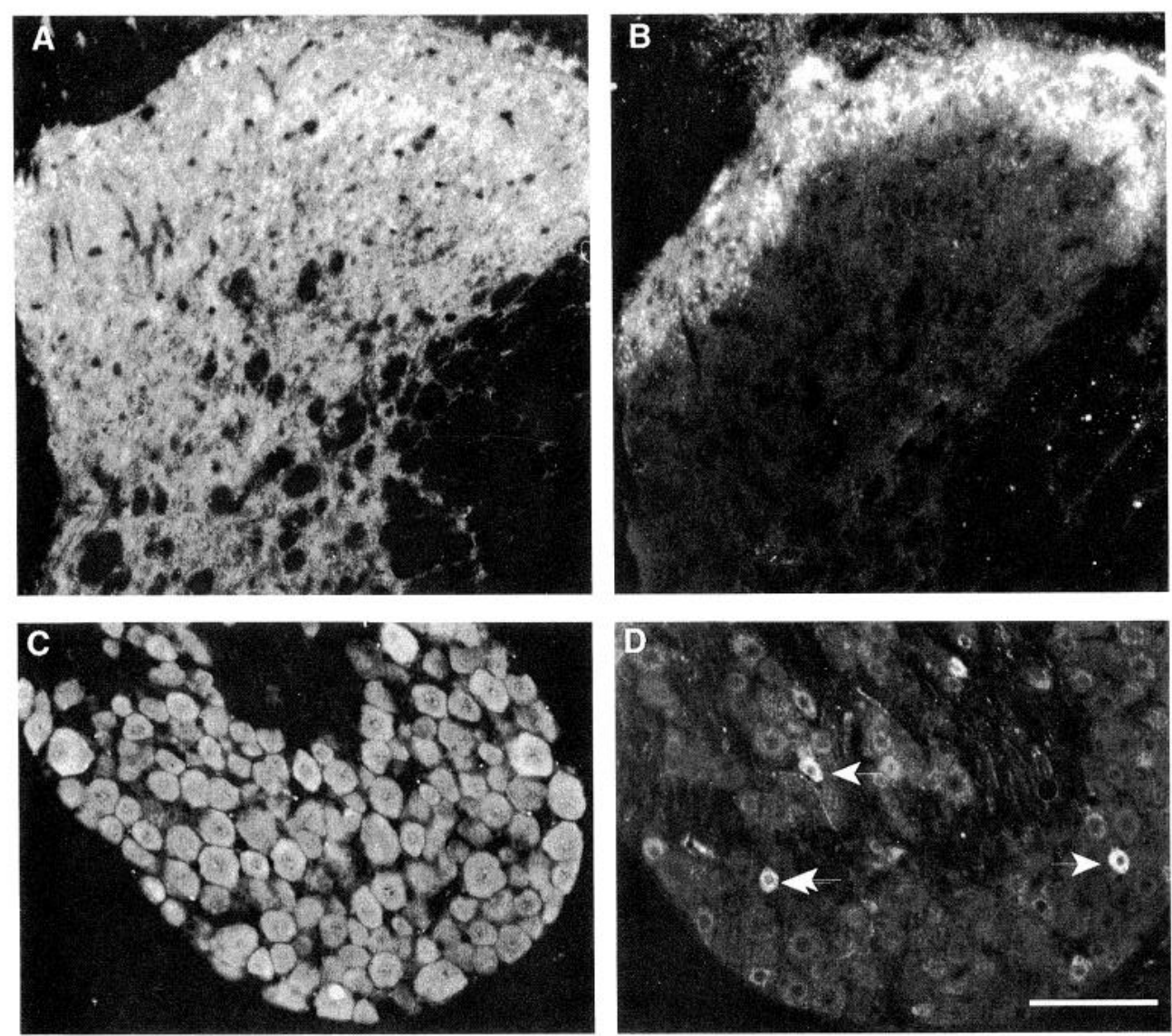

ab 1915
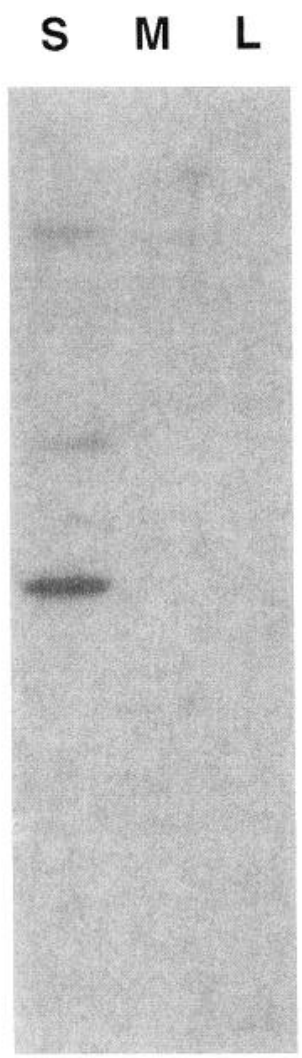

ab HM15
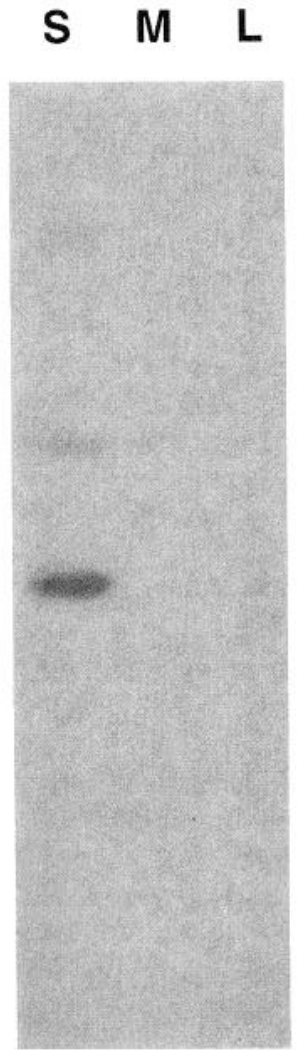

\section{mAb2}

S

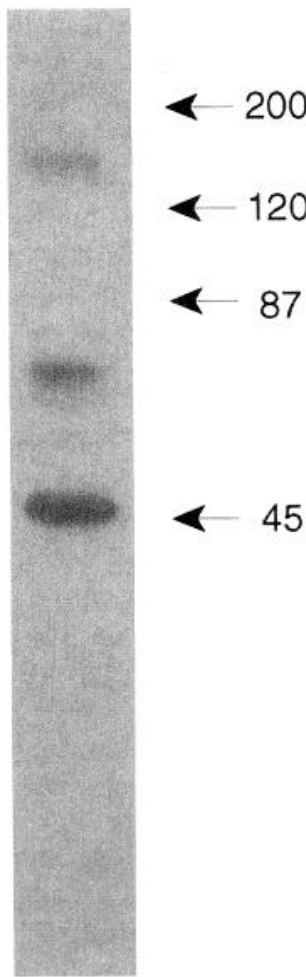

Figure 7. ARIA-like immunoreactivity in adult rat sensory neurons. Antibody 1915 labels a dense plexus in the dorsal horn and intermediate zone of the spinal cord $(A)$ and all DRG cells (C). Antibody HM15, on the other hand, labels only a subset of DRG cells comprised of small diameter neurons (D). As expected, HM15 immunoreactivity in the spinal cord is restricted to the most superficial layers of the dorsal horn $(B)$. Scale bar, $100 \mu \mathrm{m}$.

Figure 8. Western blots of adult rat tissues $(S$, spinal cord; $M$, skeletal muscle; and $L$, liver) probed with the polyclonal antibodies 1915 and HM15, and the monoclonal antibody $\mathrm{mAb} 2$. The positions of molecular weight markers are shown with arrows. There are three principal ARIA-like immunoreactive proteins of $M_{r} 45,72$, and $150 \mathrm{kDa}$ in spinal cord. 
we propose that ARIA mediates the nerve-dependent postnatal conversion of embryonic ( $\gamma$-containing) to adult ( $\epsilon$-containing) AChRs.

The continued presence of ARIA in adult motor nerve terminals is, at first glance, unexpected-particularly in light of the dramatic increase in AChR half-life that occurs after innervation (see Salpeter and Loring, 1985, for review). However, it is known that the size of the motor endplate and the total number of AChRs continues to increase in mammals well after birth (Waerhung, 1994), imposing the need to maintain a high rate of AChR synthesis. Continued local AChR synthesis at adult endplates can be inferred from studies of rodent neuromuscular junctions which showed the continued and selective expression of AChR subunit genes in subsynaptic nuclei (Merlie and Sanes, 1985; Sanes et al., 1991). In addition, there is good morphological evidence in frogs (Wernig et al., 1980) and mammals (Barker and Ip, 1966; Ip, 1974) that motor nerve terminals are constantly regressing and sprouting at normal neuromuscular junctions throughout adulthood. Since AChR turnover may increase during synaptic remodeling, trophic factors like ARIA may be essential to maintain the molecular architecture of the postsynaptic membrane in adult animals.

While we have shown that the bulk of ARIA at neuromuscular junctions appears to be concentrated in motor nerve terminals, we have also provided evidence that some ARIA molecules may be deposited in the synaptic cleft. An attenuated, more broadly distributed pattern of ARIA-like immunoreactivity remains in the endplate region after denervation (Fig. $3 D$ ). Close inspection of Figure $3 B$ suggests that a similar low intensity, perisynaptic staining pattern is also present at innervated endplates. One of the two recently published reports of $\Lambda \mathrm{RI} \Lambda$-like immunoreactiv ity at rodent neuromuscular junctions also shows residual (but reduced) staining at denervated endplates (Jo et al., 1995). We have interpreted this low level synaptic and perisynaptic staining, which persists after denervation, to represent the deposition of ARIA in the extracellular matrix at neuromuscular junctions 'after its release from the motor nerve terminal. Biochemical evidence supports the contention that ARIA is capable of binding to constituents of the extracellular matrix such as heparin (Falls et al., 1993; Loeb and Fischbach, 1995). Ultrastructural studies of the developing chick neuromuscular junction have revealed the localization of ARIA-like immunoreactivity in the synaptic and perisynaptic basal lamina (Goodearl et al., 1994). Thus, ARIA may be the basal laminal signal that activates the subsynaptic transcription of AChR subunit genes (Goldman et al., 1991; Brenner et al., 1992; Jo and Burden, 1992), thereby contributing to the accumulation of AChRs in the original synaptic sites of muscles regenerating in the absence of nerve (Burden et al., 1979). The existence of ARIA attached to basal laminal components would not, of course, rule out roles for soluble or membrane-associated isoforms of ARIA at developing endplates.

ARIA probably acts in concert with other motor nerve-derived trophic factors to regulate the accumulation of $A C h R s$ at neuromuscular junctions. Agrin, a synaptic basal lamina constitucnt that was purified based on its ability to aggregate muscle AChRs, is synthesized in motor neurons and transported down motor axons (McMahon, 1990). Agrin apparently has no effect on the rate of AChR synthesis (Godfrey et al., 1988; Wallace, 1988), and ARIA has no effect on the aggregation of surface receptors (Usdin and Fischbach, 1986). The actions of these proteins are, therefore, complementary. The relative contribution of aggregating and inducing activities in causing the accumulation of AChRs may vary in different species and at different times in the same species. Observations of Xenopus neuromuscular junctions developing in culture have shown that the local aggregation, by nerve, of previously inserted, freely diffusible AChRs-presumably as a result of entrapment by cytoskeletal and/or extracellular matrix elements-plays the predominant role in this species (Anderson and Cohen, 1977). Experiments with chick nerve/muscle cocultures have demonstrated that the appearance of newly synthesized receptors is four- to fivefold greater at sites of neurite contact than elsewhere along the myotube (Role et al., 1985). Similarly, studies in rodents have provided evidence of local, subsynaptic AChR synthesis (Merlie and Sanes, 1985; Sanes et al., 1991). In Drosophila, where glutamate is the principle excitatory neurotransmitter at neuromuscular junctions, the robust phase of glutamate receptor synthesis during late embryogenesis is localized to synaptic sites and dependent on the presence of the motor nerve terminal (Broadie and Bate, 1993).

Whereas antibody 1915 (a pan-ARIA antibody which binds to the active region of ARIA) labeled all sensory neurons, antibody HM15 (which recognizes a region of ARIA that is not essential for activity) labeled only a small subset of sensory neurons. Based on cell body size and the distribution of nerve endings, HM15-reactive DRG cells are probably glutamatergic, substance $\mathrm{P}$-containing nociceptive neurons. This result suggests that certain ARIA isoforms may be distributed among neurons of different functional class. A corollary of this observation is that different ARIA isoforms may subserve different functions. In fact, there is evidence that $\beta$-isoforms of ARIA are at least an order of magnitude more potent than $\alpha$ isoforms in the stimulation of receptor tyrosine phosphorylation in breast tumor cells (Wen et al., 1994) and in the induction of AChRs in primary skeletal muscle cells (Falls and Fischbach, unpublished observations). Differences in the spectrum of activities subserved by distinct ARIA isoforms may explain the observation that only some neurons are capable of inducing AChR accumulation in vitro. For example, primary sensory neurons, which express ARIA, are not capable of inducing neurite-associated receptor patches along contacted myotubes, even when their processes happen to overlie myotubes for several hundred micrometers (Cohen and Weldon, 1980; Kidokoro et al., 1980; Role et al., 1985). One explanation for this apparent paradox is that, although the sensory neuron expresses an ARIA and concentrates it in the nerve terminal, it is the inappropriate isoform for the induction of muscle AChRs. It is likely that the sensory neuron produces an ARIA isoform whose activity is more closely matched with its own requirements for synapse formation.

In addition to its trophic effects on skeletal muscle, ARIA and its homologs appear to possess a wide range of biological activities. Members of this family of proteins have been reported to stimulate Schwann cell proliferation (Marchionni et al., 1993), promote oligodendrocyte differentiation (Vartanian et al., 1994), restrict neural crest cells from entering neuronal lineages (Shah et al., 1994), and alter the pattern of nicotinic AChR subunit expression in neurons (Yang et al., 1994). All of these actions have been demonstrated in vitro. A first step toward understanding the function(s) of ARIA in vivo is to determine its location in the nervous system at the cellular level. Motor neurons are just one of many classes of neurons that synthesize, transport, and concentrate ARIA in nerve terminals. ARIA is also concentrated in the synaptic endings of primary sensory neurons, cer- 
ebellar granule cells, and the mossy fiber arborization within the cerebellum. Thus, the localization of ARIA protein strongly suggests a pivotal role for this molecule in synaptic development and maintenance, not only at cholinergic nerve-muscle synapses, but also in a large number of noncholinergic, interneuronal synapses.

\section{References}

Anderson MJ, Cohen MW (1977) Nerve-induced and spontaneous redistribution of acetylcholine receptors on cultured muscle cells. J Physiol (Lond) 268:757-773.

Barker D, Ip MC (1966) Sprouting and degeneration of mammalian motor axons in normal and deafferentated skeletal muscle. Proc $\mathrm{R}$ Soc Lond [Biol] 163:538-554.

Brenner HR, Sakmann B (1978) Gating properties of acetylcholine receptor in newly formed neuromuscular synapses. Nature 271:366368.

Brenner HR, Witzemann V, Sakmann B (1990) Imprinting of acetylcholine receptor messenger RNA accumulation in mammalian neuromuscular synapses. Nature 344:544-547.

Brenner HR, Herczeg A, Slater CR (1992) Synapse-specific expression of acetylcholine receptor genes and their products at original synaptic sites in rat soleus muscle fibres regenerating in the absence of innervation. Development 116:41-53.

Broadie K, Bate M (1993) Innervation directs receptor synthesis and localization in Drosophila embryo synaptogenesis. Nature 361:350353.

Buckley K, Kelly RB (1985) Identification of a transmembrane glycoprotein specific for secretory vesicles of neural and endocrine cells. J Cell Biol 100:1284-1294.

Burden SJ, Sargent PB, McMahan UJ (1979) Acetylcholine receptors in regenerating muscle accumulate at original synaptic sites in the absence of the nerve. J Cell Biol 82:412-425.

Caldwell JH, Milton RL (1988) Sodium channel distribution in normal and denervated rodent and snake skeletal muscle. J Physiol (Lond) 401:145-166

Chen MS, Bermingham-McDonogh O, Danehy FT, Nolan C, Scherer SS, Lucas J, Gwynne D, Marchionni MA (1994) Expression of multiple neuregulin transcripts in postnatal rat brains. J Comp Neurol 349:389-400.

Chu GC, Moscoso LM, Sliwkowski MX, Merlie JP (1995) Regulation of the acetylcholine receptor $\epsilon$ subunit gene by recombinant ARIA: an in vitro model for transynaptic gene regulation. Neuron 14:329-339.

Cohen MW, Weldon PR (1980) Localization of acetylcholine receptors and synaptic ultrastructure at nerve-muscle contacts in culture: dependence on nerve type. J Cell Biol 86:388-401.

Corfas G, Fischbach GD (1993) The number of $\mathrm{Na}^{+}$channels in cultured chick muscle is increased by ARIA, an acetylcholine receptorinducing activity. J Neurosci 13:2118-2125.

Corfas G, Falls DL, Fischbach GD (1993) ARIA, a protein that stimulates acetylcholine receptor synthesis, also induces tyrosine phosphorylation of a $185-\mathrm{kDa}$ muscle transmembrane protein. Proc Natl Acad Sci USA 90:1624-1628.

Corfas G, Rosen KM, Aratake H, Krauss R, Fischbach GD (1995) Differential expression of ARIA isoforms in the rat brain. Neuron 14:103-115.

Dennis MJ, Ziskind-Conhaim L, Harris AJ (1981) Development of neuromuscular junctions in rat embryos. Dev Biol 81:266-310.

Falls DL, Rosen KM, Corfas G, Lane WS, Fischbach GD (1993) ARIA, a protein that stimulates acetylcholine receptor synthesis, is a member of the Neu ligand family. Cell 72:801 815 .

Godfrey EW, Deitz ME, Morstad AL, Wallskog PA, Yorde DE (1988) Acetylcholine receptor-aggregating proteins are associated with the extracellular matrix of many tissues in Torpedo. J Cell Biol 106:1263.

Goldman D, Carlson BM, Staple J (1991) Induction of adult-type nicotinic acetylcholine receptor gene expression in noninnervated regenerating muscle. Neuron 7:649-658.

Goodearl A, Sandrock A, Yee A, Fischbach G (1994) Chick ARIA is concentrated at embryonic neuromuscular junctions. Mol Biol Cell $5: 236 a$.

Gu Y, Hall ZW (1988) Immunological evidence for a change in subunits of the acetylcholine receptor in developing and denervated rat muscle. Neuron 1:117-125.

Holmes WE, Sliwkowski MX, Akita RW, Henzel WJ, Lee J, Park JW,
Yansura D, Abadi N, Raab H. Lewis GD, Shepard HM, Kuang W, Wood WI, Goeddel DV, Vandien RL (1992) Identification of heregulin, a specific activator of p185 urbiz2. Science 256:1205-1210.

Ip MC (1974) Some morphological features of the myoneural junction in certain normal muscles of the rat. Anat Rec 180:605-616.

Jo SA, Burden SJ (1992) Synaptic basal lamina contains a signal for synapse-specific transcription. Development 115:673-680.

Jo SA, Zhu X, Marchionni MA, Burden SJ (1995) Neuregulins are concentrated at nerve-muscle synapses and activate ACh-receptor gene expression. Nature 373:158-161.

Kidokoro Y, Brass B (1985) Redistribution of acetylcholine receptors during neuromuscular junction formation in Xenopus cultures. J Physiol (Paris) 80:212-220.

Kohler G, Milstein C (1975) Continuous cultures of fused cells secreting antibody of predefined specificity. Nature 256:495-497.

Loeb JA, Fischbach GD (1995) ARIA can be released from extracellular matrix through cleavage of a heparin-binding domain. J Cell Biol, in press.

Lupa MT, Hall ZW (1989) Progressive restriction of synaptic vesicle protein to the nerve terminal during development. J Neurosci 9:39373945 .

Malmborg AC, Michaeisson A, Ohlin M, Jansson B, Borrebaeck CA (1992) Real time analysis of antibody-antigen reaction kinetics Scand J Immunol 35:643-650.

Marchionni MA, Goodearl ADJ, Chen MS, Bermingham-McDonogh O, Kirk C, Ilendricks M, Danehy F, Misumi D, Sudhalter J, Kobayashi K, Wroblewski D, Lynch C, Baldassare M, Hiles I, Davis JB, Hsuan JJ, Totty NF, Otsu M, McBurney RN, Waterfield MD, Stroobant P, Gwynne D (1993) Glial growth factors are alternatively spliced erbB2 ligands expressed in the nervous system. Nature 362:312-318.

Martinou J-C, Merlie JP (1991) Nerve-dependent modulation of acetylcholine receptor epsilon-subunit gene expression. J Neurosci 11 $1291-1299$.

Martinou J, Falls DL, Fischbach GD, Merlie JP (1991) Acetylcholine receptor-inducing activity stimulates expression of the $\epsilon$-subunit gene of the muscle acetylcholine receptor. Proc Natl Acad Sci USA 88: $7669-7673$.

Matthew WD, Sandrock AW (1987) Cyclophosphamide treatment used to manipulate the immune response for the production of monoclonal antibodies. J Immunol Methods 100:73-82.

McMahan UJ (1990) The agrin hypothesis. Cold Spring Harbor Symp Quant Biol 55:407-418.

Merlie JP, Sanes JR (1985) Concentration of acetylcholine receptor mRNA in synaptic regions of adult muscle fibers. Nature 317:66-68.

Meyer D, Birchmeier C (1994) Distinct isoforms of neuregulin are expressed in mesenchymal and neuronal cells during mouse development. Proc Natl Acad Sci USA 91:1064-1068.

Mishina M, Takai T, Imoto K, Noda M, Takahashi T, Nurna S, Methfessel C, Sakmann B (1986) Molecular distinction between fetal and adult forms of muscle acetylcholine receptor. Nature 321:406-411.

Peles E, Bacus SS, Koski RA, Lu HS, Wen D, Ogden SG, Ben Levy R, Yarden Y (1992) Isolation of the Neu/HER-2 stimulatory ligand: a $44 \mathrm{kD}$ glycoprotein that induces differentiation of mammary tumor cells. Cell 69:205-216.

Role LW, Matossian VR, O'Brien RJ, Fischbach GD (1985) On the mechanism of acetylcholine receptor accumulation at newly formed synapses on chick myotubes. J Neurosci 5:2197-2204.

Salpeter MM, Loring MH (1985) Nicotinic acetylcholine receptors in vertebrate muscle: properties, distribution, and neural control. Prog Neurobiol 25:297-325.

Sambrook J, Fritsch EF, Maniatis T (1989) Molecular cloning: a laboratory manual, $2 \mathrm{~d}$ ed. Cold Spring Harbor, NY: Cold Spring Harbor Laboratory.

Sanes JR, Johnson YR, Kotzhaner PT, Mudd J, Hanley T, Martinou J, Merlie JP (1991) Selective expression of an acetylcholine receptorlac $Z$ transgene in synaptic nuclei of adult muscle fibers. Development 113:1181-1191.

Schuetze SM, Vicini S (1984) Neonatal denervation inhibits the normal postnatal decrease in endplate channel open time. J Neurosci 4:29972302.

Shah NM, Marchionni MA, Isaacs I, Stroobant P, Anderson DJ (1994) Glial growth factor restricts mammalian neural crest stem cells to a glial fate. Cell 77:349-360.

Usdin TB, Fischbach GD (1986) Purification and characterization of a 
polypeptide from chick brain that promotes the accumulation of acetylcholine receptors in chick myotubes. J Cell Biol 103:493-507.

Vartanian T, Corfas G, Li Y, Fischbach GD, Stefansson K (1994) A role for the acetylcholine receptor-inducing protein ARIA in oligodendrocyte development. Proc Natl Acad Sci USA 91:11626-11630.

Waerhung O (1994) Postnatal development of rat motor nerve terminals. Anat Embryol 185:115-123.

Wallace BG (1988) Regulation of agrin-induced acetylcholine receptor aggregation by $\mathrm{Ca}^{++}$and phorbol ester. J Cell Biol 107:267.

Weri D, Peles E, Cupples R, Suggs SV, Bacus SS, Luo Y, Trail G, Hu S, Silbiger SM, Ben Levy R, Koski RA, Lu HS, Yarden Y (1992) Neu differentiation factor: a transmembrane glycoprotein containing an EGF domain and an immunoglobulin homology unit. Cell 69:559572.
Wen D, Suggs SV, Karunagaran D, Liu N, Cupples RL, Luo Y, Janssen AM, Ben-Baruch N, Trollinger DB, Jacobsen VL, Meng S, Lu HS, Hu S, Chang D, Yang W, Yanigahara D, Koski RA, Yarden Y (1994) Structural and functional aspects of the multiplicity of Neu differentiation factors. Mol Cell Biol 14:1909-1919.

Wernig A, Pecot-Dechavassine M, Stover H (1994) Sprouting and regression of the nerve at the frog neuromuscular junction in normal conditions and after prolonged paralysis with curare. J Neurocytol 9:277-303.

Witzemann V, Barg B, Criado M, Stein E, Sakmann B (1989) Developmental regulation of five subunit specific mRNAs encoding acetylcholine receptor subtypes in rat muscle. FEBS Lett 242:419424. 